\section{B A Institute of \\ YK Business Administration \\ 光 \\ Karachi \\ Leadership and Ideas for Tomorrow}

Business Review

Volume 6 Issue 1 January-June 2011

$1-1-2011$

\title{
A new business paradigm in the offing: Using the concept of just- in-time production
}

Aman U. Saiyed

Institute of Business Administration, Karachi, Pakistan

Follow this and additional works at: https://ir.iba.edu.pk/businessreview

Part of the Business Commons

(c) (1)

This work is licensed under a Creative Commons Attribution 4.0 International License.

\section{Recommended Citation}

Saiyed, A. U. (2011). A new business paradigm in the offing: Using the concept of just-in-time production. Business Review, 6(1), 143-152. Retrieved from https://doi.org/10.54784/1990-6587.1187

This article is brought to you by iRepository for open access under the Creative Commons Attribution 4.0 License and is available at https://ir.iba.edu.pk/businessreview/vol6/iss1/10. For more information, please contact irepository@iba.edu.pk. 


\title{
CASE STUDY
}

\section{A New Business Paradigm in the Offing: Using the Concept of Just-in-Time Production}

\author{
Aman U. Saiyed \\ Institute of Business Administration, Karachi, Pakistan
}

Cotton is truly the silver fiber of Pakistani industrial fabric. More than fifty percent of our workforce is employed, directly or indirectly, in textile manufacturing. Cotton and cotton textile are the top ranked foreign exchange earners. Even during the current recessionary period, cotton and cotton textiles produced $\$ 9.8$ billion dollars of foreign exchange for Pakistan. Table I gives a three year history of foreign exchange earned by the various cotton textile sectors for Pakistan. ${ }^{1}$

Table I

\begin{tabular}{|l|l|l|l|}
\hline & \multicolumn{3}{|c|}{ Jul-Jun (Thousands of US Dollars) } \\
\hline Textile Sectors & $2008-09$ & $2007-08$ & $2006-07$ \\
\hline Textile Group (Total) & $9,776,297$ & $10,354,218$ & $10,011,350$ \\
\hline Raw Cotton & 105,416 & 86,561 & 75,640 \\
\hline Cotton Yarn & 988,907 & $1,167,597$ & 1,075966 \\
\hline Cotton Cloth & $2,106,840$ & $2,172,879$ & $2,318,481$ \\
\hline Knitwear & $2,054,853$ & $2,134,729$ & $2,104,198$ \\
\hline Bed wear & $1,526,642$ & $1,456,417$ & $1,394,372$ \\
\hline Tents, Canvas, etc. & 983,443 & $1,204,125$ & $1,097,732$ \\
\hline Readymade Garments & 387,410 & 399,233 & 385,991 \\
\hline Other & $1,622,786$ & $1,732,677$ & $1,558,970$ \\
\hline
\end{tabular}

The importance of textile export as a foreign exchange earner for Pakistan can be comprehended by the fact that the second ranked foreign exchange earner is not a commodity but the Pakistani expatriate community working overseas ${ }^{2}$. Table II shows the breakdown of foreign export earned through remittances from the expatriate Pakistani workers over four years.

Table II

\begin{tabular}{|l|l|l|l|l|}
\hline \multirow{2}{*}{} & \multicolumn{4}{|c|}{ July-Jun (Millions of US Dollars) } \\
\cline { 2 - 5 } & 2009 & 2008 & 2007 & 2006 \\
\hline Remittances & 7,811 & 6,452 & 5,494 & 4,600 \\
\hline
\end{tabular}

Lately, the textile industry has begun to feel the bite of foreign competition. With Bangladesh and Sub-Saharan African countries winning quota-free textile 
import benefits from the U.S. and the European Union, it is becoming harder and harder for Pakistani textile exporters to compete with them. According to All Pakistan Textile Manufacturers Association (APTMA), hundreds of small and medium sized manufactures have shut down their operations and the larger ones (with a few exceptions) are having a hard time staying profitable. They are trying different means to survive. Some of the larger ones have moved all or part of their manufacturing operations to Bangladesh and Sub-Saharan countries or are moving away from manufacturing to wholesaling or even retailing of foreign made textiles.

The cotton textile industry is facing three kinds of problems:

- Increasing competition

- Searching for new markets

- Increasing costs

As cotton textile emerges as the purest form of commodity, we can rest assured that the competition against Pakistani textile will increase rather than decrease. There are new entrants in textile manufacturing. Countries such as Botswana, Viet Nam, Cambodia and Laos have entered into simple textile manufacture while China, India and Bangladesh are moving from simple textiles into sophisticated conversions such as scientific textiles and high-end garment making. In such circumstances, Pakistani textile business will have to match the competitors with better products and exclusive branding. They also need to look for new markets.

\section{INCREASING COMPETITION}

Pakistan's traditional markets for their textile products have been the U.S. and European Union. As mentioned earlier, due to quota-free imports from Bangladesh and Sub-Saharan countries, Pakistan's share of this traditional market has been in decline. Although Pakistani textiles have sold more and more in quantity, the dollar value or per kilogram price for their products have been either unchanged or has very slightly increased. The one cotton textile sector where per kilogram price has increased is cotton garments. Unfortunately, this is one sector where the quantity exported went down. In fiscal year 2006-07 Pakistan exported 44,444 dozen garments while in 2007-08 there were only 38,607 dozen garments exported. ${ }^{3}$ Table III

\begin{tabular}{|l|l|l|l|l|l|}
\hline \multirow{2}{*}{ Textiles } & \multicolumn{5}{|c|}{ US Dollars Per Kilogram } \\
\cline { 2 - 6 } & $2003-04$ & $2004-05$ & $2005-06$ & $2006-07$ & $2007-8$ \\
\hline Cotton Yarn & 2.26 & 2.09 & 2.06 & 2.15 & 2.30 \\
\hline Cotton Cloth & 0.71 & 0.78 & 0.80 & 0.92 & 0.01 \\
\hline Tents and Canvas & 2.34 & 2.52 & 2.27 & 2.67 & 3.19 \\
\hline Bed wear & 5.66 & 5.57 & 5.58 & 5.58 & 5.66 \\
\hline Garments & 36.00 & 32.32 & 35.18 & 34.82 & 38.81 \\
\hline
\end{tabular}


Some of the Pakistani manufacturers, specially the smaller ones, are now trying to work out some or all of the three problems. They are trying to find new markets in yet unexplored territories such as South America and Africa and finding ways to bring down their production costs. These manufacturers, due to their smaller size, have better maneuverability and more options to switch to new customers, change their production models and go for different kinds of value-added textile products.

\section{LOOKING FOR NEW MARKETS}

In the last couple of years, there has been a marked change in the pattern of textile exports. While Pakistan still exports the bulk of its cotton textiles to the traditional markets such as the U.S., UK and other countries of the European Union, the growth markets are elsewhere. Pakistan's textile trade with US has been declining and short of a policy change by the US government there is no likelihood of reversal of this pattern. Mr. Michael Kugelman, program associate with the Asia Program at the Woodrow Wilson International Center for Scholars in Washington, DC believes that the current trade position will not turn favorable in the near future. He writes that "short of inking a free-trade agreement with the US (presently a nonstarter), Pakistan has little assurance of gaining better access to American markets anytime soon"4. In his opinion, Pakistan ought to diversify its exportable products and look for other markets to export its products. The numbers bear him out. Table IV below shows the amounts of cotton textiles exported (in thousands of US dollars) to various countries for fiscal years 2006-07 and 2007-08 and the net percentage change from 2006-07 to 2007-08. It appears that some of the more enterprising exporters are now moving to markets where there is less competition for their products and better opportunities to enhance profits. Such new markets are Norway, Turkey, Australia and New Zealand. ${ }^{5}$

Table IV

\begin{tabular}{|l|l|l|l|}
\hline \multicolumn{1}{|c|}{ Country } & \multicolumn{1}{c|}{$2007-08$} & \multicolumn{1}{c|}{$2006-07$} & \multicolumn{1}{c|}{$\%$ Change } \\
\hline USA & 531,794 & 651,114 & -18.33 \\
\hline UNITED KINGOM & 156,570 & 174,806 & -10.43 \\
\hline CANADA & 17,110 & 19,760 & -13.41 \\
\hline BELGIUM & 54,473 & 60,467 & -10.06 \\
\hline TURKEY & 22,771 & 13,675 & 66.52 \\
\hline NORWAY & 5,990 & 3,387 & 76.85 \\
\hline BRAZIL & 2,688 & 1,246 & 115.73 \\
\hline POLAND & 1,510 & 969 & 55.83 \\
\hline AUSTRALIA & 8,792 & 8,607 & 2.15 \\
\hline
\end{tabular}




\section{CONTROLLING AND MANAGING COSTS}

While studying Supply Chain Management (SCM) we look at the nature of costs to determine the profitability of a product. SCM allows us to look not just at the production phase of costing but at the entire chain of purchasing, manufacturing and marketing process. This requires us to calculate costs associated with acquiring and maintaining raw material inventory, application of costs during work-in-process, storing finished goods and finally distributing finished goods to the ultimate consumers $^{5}$. This analysis indicates that the longer the SCM process the higher the costs that the manufacturer and distributors are to bear. The end result of SCM is that the business people can increase their profitability by shortening the supply chain process. ${ }^{6}$

One approach that the manufacturers use to shorten the manufacturing process is to use 'demand pull' rather than 'supply push' manufacturing. The contemporary management theory advocates a demand pull rather than a supply push production approach. The Japanese have perfected this approach into Just-in-Time Inventory and Just-in-Time (JIT) Production. The JIT Production model awaits orders from the customers. The production process thus results in rapid production and immediate delivery keeping the employed working capital extremely efficient. In JIT production, demand triggers each step of the production function. The manufacturer is therefore, able to keep the materials inventories at a very low level, requires minimum set-ups and delivers the finished goods immediately to the customers thus avoiding finished goods inventory build-up. JIT production or lean production, results in cost savings and production efficiencies for the manufacturer. ${ }^{7}$

\section{INCREASING COSTS}

Pakistani manufacturers have so far been able to control their costs by reducing labor costs. They have switched from keeping permanent labor to contract labor, have moved production from major cities to smaller cities, and have avoided going into value added production fearing that this would require them to hire skilled labor that is more expensive than semi-skilled ones. These tactical moves have only delayed their day of reckoning. When they lower their labor costs through such means, other countries, such as Bangladesh with much lower costs, beat them on their own turf. When they lower the quality of their products, countries with less skilled labor such as Laos and Cambodia start matching them with their products. Their salvation therefore, rests in better and more efficient use of resources and not in lowering costs through hiring cheap labor and compromising on quality. 


\section{COST MANAGEMENT}

Production costs consist of:

- Direct materials

- Direct labor, and

- Overhead

Costs in the first two categories are called prime costs. Direct material and direct labor costs can be identified and traced to the production process and are directly charged to the units produced. Overhead costs are charged to production using a predetermined overhead rate.

Costs classified as direct are alternatively called variable costs. These costs directly increase or decrease with the change in production activity. Costs considered indirect may or may not be variable. However, majority of these indirect costs are considered fixed. Fixed costs mainly consist of administrative expenses, rent, property taxes, and depreciation associated with nonmanufacturing plant and properties. These costs don't change with the change in activity. These costs are the ones that affect the economy of scale. The more the business works close to its full capacity the more of these costs spread over the units produced lowering the per unit cost. If price remains the same, lower per unit costs result in higher profit to the business. One way to lower per unit cost is to keep the fixed cost per unit as low as possible. This would require companies to rent the facilities rather than own them. Small and medium size operation can do that with better plans and active and efficient management of time. This business strategy where the firm keeps its fixed cost to the minimum thus immediately becoming profitable is called operating leverage.

\section{A CASE STUDY}

During a semester-long assignment, a group of my students led by Naved Kamran Khan in the Advanced Management Accounting class conducted a study of a the production process of a businessman who is actually applying all the above mentioned methods to increase his sales and reduce costs thereby increasing profits. The study was conducted in November of 2008 in North Karachi. The purpose of conducting this study and publishing is to introduce this flexible method of manufacturing to other entrepreneurs in textile business.

During our study of the textile business in North Karachi, which is the hub of small textile and allied manufacturing, we came across a unique model of textile manufacturing and marketing business. This is a highly profitable operation and is 
worth studying for the sake of making small and medium size textile businesses competitive and profitable.

The firm (if it is called a firm) has a very simple business process. They receive orders locally or internationally. Production process starts when the firm has the actual order in hand. The firm goes out and hires the whole production apparatus. They hire the space, equipment, and the workers both skilled and un-skilled, and start production. Once production is complete and the orders are delivered, they shut down the operation, pay off the workers and return the physical facilities to the owners.According to the owner of the firm, Mr. Alam Khan, New Karachi business cluster always has surplus of space and equipment all the time and you can always hire skilled and unskilled labor that is willing to work for contracts of any duration. As long as they are satisfied with the contract rate they are willing to work. Mr. Alam Khan claims that his production approach has created a virtual work environment that is beneficial to him, the owners of facilities (both space and equipment), and the workers.

To keep the process efficient and simple, Mr. Khan only deals in bed linen. He only takes one order at a time. This allows him to deliver quality while avoiding hiring and keeping skilled labor on a permanent basis. Mr. Khan is a true entrepreneur. He runs the business himself, has no administrative or other professional help and directly deals with both the suppliers and contractors. He does not have an accountant and keeps all his expenses (he has no long term or fixed costs) in an old fashioned register. He keeps one expense register for one order. $\mathrm{He}$ therefore, easily verifies his costs pertaining to that order and by subtracting the costs from the revenue of that particular order can determine the profitability of the order.

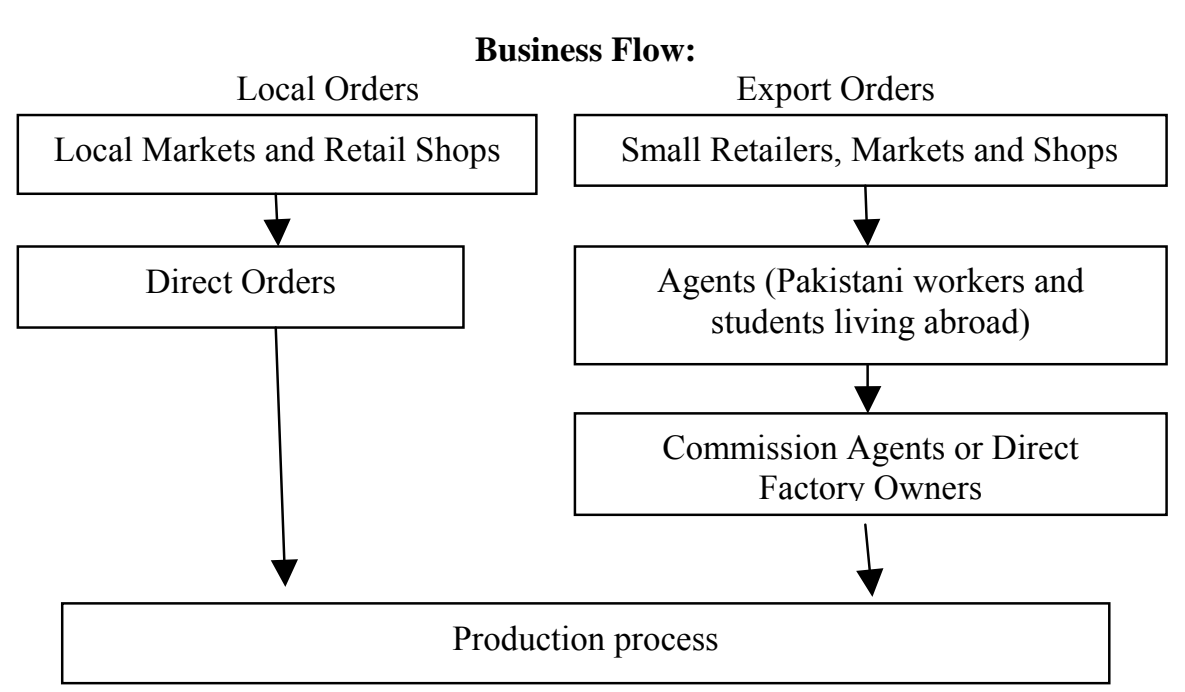

148 
The IBA students worked with the owner, they copied information from the registers for several orders for bed linen and developed the cost structure for the products.

They found out that Mr. Khan only makes bed linen in three sizes; single, queen and king. He is currently serving small orders for local markets and small and medium-size orders for Australia and New Zealand.

His resource accumulation and usage is shown in the following table:

\begin{tabular}{|c|c|c|}
\hline Raw Materials & Space and Equipment & Labor \\
\hline Agents/Kapra markets & $\begin{array}{l}\text { Renting space in North } \\
\text { Karachi }\end{array}$ & Labor agents (jobbers) \\
\hline $\begin{array}{l}\text { Warehouses } \\
\text { Factories, stock lots, etc }\end{array}$ & $\begin{array}{l}\text { Renting cutting and } \\
\text { stitching machines }\end{array}$ & $\begin{array}{l}\text { Direct hire through old } \\
\text { contacts }\end{array}$ \\
\hline
\end{tabular}

The production process consists of:

- Renting of space and equipment to meet the order.

- Buying raw material from any of the above three sources in accordance with the order received from a local buyer or a buyer from Australia or New Zealand.

- Hiring the required labor size to finish the order on time.

- Producing the ordered product (s).

- Packing and shipping the order to the buyer or his agent.

The cost sheet prepared from the data recorded in the expense registers shows the cost of production and shipping of the three types of bed sheets per piece:

\begin{tabular}{|c|l|l|l|c|r|c|}
\hline Size & Labor & \multicolumn{2}{|c|}{ Materials } & $\begin{array}{c}\text { Overhead } \\
\text { \&Packing }\end{array}$ & $\begin{array}{c}\text { Total } \\
\text { (Rs.) }\end{array}$ & $\begin{array}{c}\text { *Total } \\
\text { AUS\$ }\end{array}$ \\
\hline Single & Rs. 25 & 3 mtrs. & Rs.130/mtr. & Rs. 152 & 567 & 10.30 \\
\hline Queen & Rs. 35 & $4.5 \mathrm{mtrs}$. & Rs.140/mtr. & Rs. 152 & 817 & 14.85 \\
\hline King & Rs. 45 & 5 mtrs. & Rs.145/mtr. & Rs. 152 & 922 & 16.75 \\
\hline
\end{tabular}

*Using a conversion rate in effect in Nov 2008 of Rs. 55 to one AUS\$

The student calculated the overhead and packing cost per piece using the following numbers 


\begin{tabular}{|l|r|}
\hline \multicolumn{2}{|c|}{ Fixed Overhead } \\
\hline Rent & Rs. 13,000 \\
\hline Salary (security guards, etc.) & 20,000 \\
\hline Maintenance & 10,000 \\
\hline Fuel & $\underline{10,000}$ \\
\hline Total Per Month & Rs. 5300 \\
\hline Total Number of Pieces Per Month (Avg.) & R50 \\
\hline Per Piece Overhead Rate (Rs. 53,000/650) & $\underline{\text { Rs. 70 }}$ \\
\hline Per Piece Packing Cost & $\underline{\text { Rs. 152 }}$ \\
\hline Total Overhead and Packing Cost Per Piece & \\
\hline
\end{tabular}

After packing, the bed sheets are shipped to Australia or New Zealand. The firm realizes a net sale price of twice its cost of production and shipping. His net realized price for one king size beds sheet is therefore, approximately AUS\$34. At the exchange rate of 1 AUS\$ equal to 0.6555 US\$, in effect on November 31, 2008, this converts to US\$22. ${ }^{8}$ A king size bed sheet normally weighs about 1 kilogram. This firm therefore, is exporting bed linen to Australia at almost four times the price of $\$ 5.66$ quoted by APTMA for bed linen exported by Pakistan in 2008. The owner thinks and we agree that his business model is highly profitable and he does not have to change it for anything.

\section{SUGGESTIONS}

If Mr. Alam Khan has such a promising and profitable model and he does not wish to change it why don't we persuade other small and medium-sized textile manufacturers to adapt to his model? This can be done in three ways:

- Propagating his way of doing business

- Getting government agencies such as TDAP to actively involved in encouraging such efforts

- Getting trade bodies to enlist the exporters to try this model

\section{PROPAGATING HIS WAY OF DOING BUSINESS}

The purpose of writing this paper is to introduce the concept of virtual production as a Pakistani entrepreneurship to the academic community. We have always praised the way the Japanese or the Americans practice JIT inventory management or JIT production management. We have signally failed to find out if this method of management is practiced in our own country. In these times when we have surplus capacity in both human resource and physical facilities, we should be encouraging people to learn this method of production and export. IBA is in a unique 
position to take the lead in this respect. We can hold seminars and lectures to get entrepreneurs to look into this way of doing business. IBA has established the Center for Entrepreneurship. This center can be used to inspire other entrepreneurs to try this approach.

\section{TDAP}

TDAP which replaced the Export Promotion Bureau is more actively involved in encouraging Pakistani businesspersons to export. They have the budget, the skills and the contacts to be used to bring the entrepreneurs together. TDAP has also information on foreign importers who want to do business with Pakistani exporters. They are in an ideal position to bring new business to small manufacturers and exporters.

\section{TRADE BODIES}

There are several trade bodies working for the welfare of textile related business. Trade bodies such as Pakistan Readymade Garments Association, Pakistan Hosiery Manufacturers Association, and Pakistan Bed Linen Manufacturers Association can be used to bring the two groups of people (the owners of production facilities and the exporters) together. They can act as a clearing house or rather like an employment agency bringing the plant owners and the manufacturers together. At any given time, there is a surplus of plant capacity and manufacturers with export orders and plant deficiency. These trade bodies can approach the two groups of people, even for a fee, to work together. This will not only give an impetus to foreign trade, it would also give the trade bodies an opportunity to serve their members better. 狊A

\section{REFERENCES}

1. http://www.sbp.org.pk/Ecodata/Export_Receipts_by_Commodity.pdf

2. http://www.sbp.org.pk/Ecodata/homeremmit/remittance.pdf

3. http://www.aptma.org.pk/Pak_Textile_Statistics/ecml.asp past years

4. Dawn, Monday, January 25, 2010 - Page 7.

5. http://www.aptma.org.pk/Pak_Textile_Statistics/cwermg.asp

6. Horngren, Datar and Foster, Cost Accounting - A Managerial Emphasis, $11^{\text {th }}$ Edition, Peasrson Education (Singapore) Pte. Ltd., Indian Branch, 482 F. I. E. Patparganj, Delhi 110092, India, Page 10.

7. Ibid, Page 696-697.

8. http://www.economist.com/markets/currency/fullconverter.cfm?exch quant ity $=1 \&$ exch date $=30 \% 2$ F11\%2F08\&exch_dFormat=normal\&exchfrom=USD\&exchto=AUD 
https://ir.iba.edu.pk/businessreview/vol6/iss1/10

DOI: https://doi.org/10.54784/1990-6587.1187

Business Review - Volume 6 Number 1

January - June 2011

Wise and effective leadership is practiced only by those who have overcome, as far as humanly possible, all limitations of the mind. Management functions within no single frame of reference. Its scope is as wide as that of the whole operation, as broad as life itself. Whatever constricts the mind must be overcome. As the ladder of responsibility is climbed, each successive step demands more and more flexibility of intellect, more and more capacity to comprehend divergent forces, and more and more power to correlate them into a unified whole.

In the last analysis, only the man himself can correct and overcome the imbalance of performance that specialization creates. Only he can undertake and achieve the broad cultivation of the mind that brings the wisdom, the tolerance, and the intellectual fortitude which are the hallmarks of distinguished industrial leadership.

Clarence B. Randall, The Folklore of Management pg. 87-88 